\title{
ENGELS: DA CRÍTICA DA ECONOMIA POLÍTICA À CRÍTICA AO DIREITO
}

\author{
ENGELS: FROM THE CRITIC OF POLITICAL ECONOMY TO CRITIC OF LAW
}

Vitor Bartoletti Sartori*

\begin{abstract}
RESUMO
A partir daquilo que José Chasin chamou de análise imanente, analisaremos o percurso engelsiano tendo em conta sua mudança de ênfase, de uma crítica à economia política a uma crítica ao Direito. A partir da tensão entre o modo de exposição de Engels e o conteúdo específico que ele procurou divulgar, mostraremos que não há uma ruptura substantiva na posição do autor, mesmo que seu enfoque seja diferente em um momento em que o movimento socialista ganha destaque na esfera pública e em que o terreno do Direito parece central. No esboço de 1844, Engels traz a crítica à economia política imediatamente correlacionada às críticas à religião, à política e ao Direito; porém, no final de sua vida, e buscando divulgar as descobertas de Marx, o autor do Anti-Düring vem a enfocar a crítica ao Direito em sua exposição. Isto se dá, tanto porque seus adversários acabam tendo o Direito por central, quanto devido à relevância e às armadilhas das lutas que se colocam em torno dos usos do aparato estatal.
\end{abstract}

PALAVRAS-CHAVE: Engels. Crítica da economia política. Crítica ao Direito. Marxismo

\begin{abstract}
Based on what José Chasin called an immanent analysis, we will analyze the Engelsian course considering its change in emphasis, from a critique of political economy to a critique of Law. Based on the tension between Engels' mode of exposure and the specific content that he must disclose, we will show that there is no substantial break in the author's position, even though his emphasis is different at a time when the socialist movement grows and where the field of law, even though it is not the central one, seems to be. In his famous Draft of 1844, Engels criticizes de political economy in its immediate relation with the critic of religion, politics and Law; on the later days of his live, however, the author of Anti-Düring has an especial emphasis on the critic of Law. It happens because of his adversaries emphasis, focused on rights and Law but also because of the importance, as well as the traps, involved on the struggle on the State apparatus.
\end{abstract}

KEYWORDS: Engels. Critic of Political Economy. Critic of Law.

\footnotetext{
* Mestre em História pela PUC SP, doutor em filosofia do Direito pela USP e professor de hermenêutica na Faculdade de Direito da UFMG. E-mail: vitorbsartori@gmail.com.
} 


\section{INTRODUÇÃO}

Em 2020, completam-se duzentos anos do nascimento de Friedrich Engels. E podemos dizer que, ao tratar dele, é impossível deixar de remeter ao seu grande amigo, Karl Marx.

Isso tem um aspecto dúplice. Ao mesmo tempo em que, ao tomar-se em conta a produção conjunta dos dois autores, aspectos da obra de cada um puderam ser esclarecidos, ocorreu também certa confusão: de um lado, não foram poucas as vezes em que se incorreu em simplesmente equiparar o estatuto do texto de um autor ao do outro; doutro lado, houve marxistas que pareceram imputar a Engels praticamente todos os vícios do marxismo do século XX. E, em verdade, nenhuma dessas “soluções” é minimamente aceitável (SARTORI, 2015). Se há de se lembrar sempre da proximidade das teorizações de Marx e de Engels, não se pode deixar de notar certos aspectos que os distanciam, ao menos quanto às suas ênfases, exposição e tonalidade mais ou menos ligadas às polêmicas mais imediatas (SARTORI, 2020a). Assim, nos duzentos anos do nascimento desse importante autor, vale aprofundar alguns aspectos que dizem respeito a uma das grandes temáticas dos dois autores mencionados, a crítica da economia política. A partir de uma análise do texto do próprio Engels, ao comparar seu Esboço para uma crítica da economia política (1844) com sua obra tardia, procuraremos explicitar aspectos destacados do tema, passando pelas diferentes ênfases do pensador.

No presente artigo, intentamos demonstrar que a economia política nunca deixa de ser uma preocupação essencial para nosso autor. Porém, o modo pelo qual isto se dá muda; se em 1844, na época de seu "genial esboço", para que se usem as palavras de Marx (2013), o fio condutor da exposição engelsiana estava na crítica da economia política e das relações materiais de produção, no final de sua vida, e após a morte de Marx, sua exposição tem como organizadora, não tanto a crítica da economia política, mas certa centralidade do debate político e da crítica ao Direito. A partir daquilo que José Chasin chamou de análise imanente ${ }^{1}$, demonstraremos as determinações essenciais da obra engelsiana sobre o aspecto mencionado

\footnotetext{
${ }^{1}$ Como diz Chasin: "tal análise, no melhor da tradição reflexiva, encara o texto — a formação ideal — em sua consistência autossignificativa, aí compreendida toda a grade de vetores que o conformam, tanto positivos como negativos: o conjunto de suas afirmações, conexões e suficiências, como as eventuais lacunas e incongruências que o perfaçam. Configuração esta que em si é autônoma em relação aos modos pelos quais é encarada, de frente ou por vieses, iluminada ou obscurecida no movimento de produção do para-nós que é elaborado pelo investigador, já que, no extremo e por absurdo, mesmo se todo o observador fosse incapaz de entender o sentido das coisas e dos textos, os nexos ou significados destes não deixariam, por isso, de existir [...]" (CHASIN, 2009, p. 26).
} 
ao ter em conta seu primeiro grande texto e os seus últimos textos, essencialmente mais polêmicos e voltados à imprensa socialista.

\section{O GENIAL ESBOÇO E A IMANÊNCIA DA EXPOSIÇÃO DO JOVEM ENGELS}

Marx (1996a, p. 140) ${ }^{2}$ foi claro ao distinguir exposição e pesquisa; disse que somente depois de "captar detalhadamente a matéria" seria possível "expor adequadamente o movimento real". Com isso, buscou explicitar as determinações da própria realidade efetiva ao mesmo tempo em que isso não se daria necessariamente ao trazer as categorias na ordem em que elas aparecem na história, mas de acordo com a conexão íntima delas na própria objetividade do real (MARX, 2011). Ou seja, no autor, há uma relação importante entre pesquisa e exposição, relação esta que chegou a trazer à tona debates dentro do próprio marxismo $^{3}$. E, com isto, talvez seja possível dizer que a análise da exposição de um autor relacionado a Marx pode ter algum relevo na compreensão do modo pelo qual se passa determinado conteúdo. Em Engels, acreditamos, isso é essencial sobre diversos aspectos (SARTORI, 2020a) e se dá tanto ao analisar seus textos da década de 1840 quanto ao tratar de suas últimas intervenções, ligadas sobretudo a polêmicas em torno do desenvolvimento do movimento socialista do final do $\mathrm{XIX}^{4}$.

Para que adentremos em nosso tema de modo mais direto, é preciso que se aponte que o primeiro texto de grande influência no marxismo por parte de Engels - Esboço de uma crítica da economia política - traz diversos temas concatenados, passando pela crítica à religião, pela economia política, pela política, explicitando a necessidade de supressão da totalidade das determinações burguesas da sociedade de sua época. Ou seja, sua exposição não é essencialmente temática ${ }^{5}$ e traz a imanência das relações de uma época à tona de modo nem sempre fácil de se apreender. As conexões do material pesquisado aparecem em seu texto remetendo ao todo das relações sociais de uma época. Podemos dizer, portanto, que há uma

\footnotetext{
${ }^{2}$ Veja-se a passagem na íntegra: "é, sem dúvida, necessário distinguir o método de exposição formalmente do método de pesquisa. A pesquisa tem de captar detalhadamente a matéria, analisar as suas várias formas de evolução e rastrear sua conexão íntima. Só depois de concluído esse trabalho é que se pode expor adequadamente o movimento real. Caso se consiga isso, e espelhada idealmente agora a vida da matéria, talvez possa parecer que se esteja tratando de uma construção a priori" (MARX, 1996a, p. 140). Para uma análise da importância dela na crítica marxiana a Hegel e ao neo-hegelianismo, ver Sartori (2014).

${ }^{3}$ Para uma posição que gosta de enfatizar certa relação de Marx com Hegel, ver Reichelt (2013) e, de modo mais mediado e ponderado, Grespan $(2012,2019)$. Contra tal posição, confira Alves (2013).

${ }_{5}^{4}$ Sobre o assunto, ver Sartori (2018a, 2018b).

${ }^{5}$ Como procuraremos mostrar depois, a divisão em temas é bastante cara ao autor no final de sua vida, por exemplo em sua polêmica com Eugene Düring.
} 
correlação explícita entre o modo de exposição engelsiano e certo modo de, na época, lidar com o conteúdo da sociedade civil-burguesa.

$\mathrm{Na}$ crítica à economia política, não se teria só apontamentos sobre as relações materiais de produção, mas também diversos elementos que compõem uma época.

E, com isso, o autor ataca certa ênfase na política, muito comum aos neo-hegelianos no clamor pelo Estado político (SARTORI, 2018a), ao dizer que "a política não pensou em examinar, em si e para si, os pressupostos do Estado" (ENGELS, 1979, p. 3) Assim, no espírito da época, e em embate tanto com os neo-hegelianos quanto com os expoentes daquilo que posteriormente chamaria de socialistas utópicos (ENGELS, 1962), Engels realiza uma crítica à política e à hipostasia do Estado. Se Marx, também nessa crítica, em Sobre a questão judaica, apontaria para o egoísmo da sociedade civil-burguesa, nosso autor diz que se tem nessa sociedade "esta economia política, ou melhor: esta ciência do enriquecimento, nascida do logro mútuo e da ambição dos comerciantes" e ela "traz na fronte a marca do egoísmo mais repugnante" (ENGELS, 1979, p. 2). Ou seja, o egoísmo apontado primeiramente por Hesse e depois por Marx remeteria à economia política.

$\mathrm{Na}$ crítica da economia política, ter-se-ia o questionamento daquilo que aparece na esfera pública e é efetivo na esfera política. Os pressupostos do Estado estariam, não só na sociedade, mas nas relações econômicas abordadas pela economia política. Estas relações conteriam em si contradições que, se desenvolvidas, levariam a consequências importantes para o destino da época em que se colocava nosso autor. A crítica à política e à religião levaria a tratar dos pressupostos destas esferas; e, com isso, à explicitação das mencionadas consequências. Abordar a economia política, portanto, seria importante porque aquilo que é tratado nesta ciência dá base ao que aparece como real e efetivo em outras esferas, como na política e na religião. A necessidade de criticar essa "ciência do enriquecimento" não seria um capricho, mas uma necessidade em uma sociedade marcada pela propriedade privada e pelo egoísmo (SARTORI, 2020b).

Assim, abordar o Estado seria possível ao analisar com profundidade a propriedade privada, enxergando as contradições que a marcam, bem como as possibilidades daí, contraditoriamente, decorrentes.

Sobre isso, ao tratar da teologia e da filosofia - tal qual o faz Marx na Crítica da filosofia do Direito de Hegel, introdução, diga-se de passagem (SARTORI, 2020b) —, Engels traz elementos importantes de sua crítica: “assim como a teologia deve ou voltar à fé cega ou avançar até a livre filosofia, é preciso que a liberdade de comércio produza, por um lado, a 
restauração dos monopólios e, por outro, a supressão da propriedade privada" (ENGELS, 1979, p. 4). Tem-se aí tanto aspectos relacionados às formas ideológicas pelas quais os homens tomam consciência das contradições sociais ${ }^{6}$ quanto ligados mais diretamente às formas sociais mesmas: de acordo com o raciocínio engelsiano, tal qual o desenvolvimento da teologia levaria à supressão e à superação dela, o movimento interno da economia política poderia levar à abolição de sua própria base, a propriedade privada. Ou seja, tal qual o centro organizador do medievo passava pela teorização da teologia, na moderna sociedade civilburguesa, ter-se-ia a teoria relacionada à filosofia. Porém, ao enxergar o presente, haveria algo de grande relevo a se apontar: o essencial não seria mais a teologia, ou mesmo a filosofia (esta última bastante apegada à resolução política dos conflitos sociais), mas na economia política e na propriedade privada. Seria preciso, portanto, uma crítica à economia política e à sua base, que, em verdade, traria o pressuposto do Estado, da teologia e do teorizar filosófico.

Há alguns pontos a se notar sobre o assunto: o primeiro deles diz respeito à correlação existente entre crítica da religião, da política e da economia política. Ela é marcante na exposição engelsiana. Depois, é preciso que se note que a interconexão entre essas críticas aparece na linha vermelha que guia o Esboço. Ao passar pela crítica da economia política, tem-se o questionamento das bases da política e da própria religião.

Ou seja, a exposição engelsiana é muito mais imanente que sistemática nesse momento. Explicita as interconexões das categorias tanto em suas formas de aparecimento quanto analisando seu movimento, que vem a ser um predicado do desenvolvimento do comércio, do monopólio, da propriedade privada, daquilo trazido pela economia política. Ao confrontar-se com a economia política, nosso autor é obrigado a trazer ao debate o Estado, a religião, a correlação entre indivíduo e gênero. Com isso, mostra como que as categorias destes diferentes campos não são realidades estanques, mas sim intimamente conectadas e presididas por aquilo que se coloca de modo mais explícito nas relações econômicas. Ao invés de fórmulas gerais sobre a prioridade de esfera $\mathrm{x}, \mathrm{y}$, ou $\mathrm{z}$, tem-se uma abordagem que explicita a efetividade das categorias e mostra como que suas gêneses, estruturas e funções se correlacionam necessariamente.

O Esboço traz um ponto de partida que nosso autor não abandonará durante toda a sua vida, portanto. No transcorrer de sua crítica, Engels explicita esse aspecto, que será enunciado muitas vezes como um princípio basilar da crítica materialista que ele e Marx levarão adiante durante sua vida.

\footnotetext{
${ }^{6}$ Sobre este aspecto das formas ideológicas, ver Marx (2009) e Lukács (2013).
} 
Ou seja, o texto traz certa correlação íntima entre pesquisa e exposição; a descoberta engelsiana é explicada e analisada no texto. Mesmo que existam muitos elementos a serem desenvolvidos ainda (lei do valor, por exemplo), deparamo-nos com uma correlação entre infraestrutura e superestrutura — para que se utilizem os termos posteriores de Marx (2009) ${ }^{7}$ - que deve ser vista como algo basilar à “concepção materialista da história”. As analogias trazidas por Engels entre a teologia e a economia política, portanto, são abundantes. ${ }^{8}$ Elas remetem ao movimento da própria sociedade, tendo-se a relação imanente entre a chegada da moderna sociedade civil-burguesa e esses aspectos. E, ao se ter em conta essa sociedade que mencionamos, há de se destacar que ela, em correlação com o Estado e com a família, colocase na esfera da eticidade (Sittlichkeit). Ela, que fora essencial a um texto bastante discutido na época, os Princípios da filosofia do Direito, de Hegel (2003), tem grande relevo no texto que agora analisamos.

Tal categoria, central à filosofia hegeliana, e à filosofia do Direito em especial, tem importância decisiva no Esboço. De um lado, Hegel (2018, p. 11) destaca:

O crime é o juízo infinito, que nega, não apenas o direito particular, mas a esfera universal, o direito enquanto direito. $\mathrm{O}$ crime tem, de fato, correção por ser uma ação efetiva; mas, porque ela se relaciona de modo completamente negativo com a eticidade, que constitui sua esfera universal, ela é contrassensual.

Tal passagem, que é criticada por Engels e por Marx posteriormente (MEDRADO, 2018), remete a certa centralidade do Direito e da política na teoria hegeliana (LUKÁCS, 2013). Se para o autor idealista o objetivo do crime tem uma ação de dissolução sobre a eticidade, para o autor do Esboço, a coisa se dá de outro modo: ele destaca que a economia política e seus pressupostos trazem consigo certa dissolução da eticidade, uma antieticidade (Unsittlichkeit). Ou seja, não seria o crime - o qual se configuraria como uma espécie de negação do direito - que exerceria tal desagregação na família, na sociedade civil-burguesa e

\footnotetext{
${ }^{7}$ Diz Marx sobre as relações sociais de produção que "a totalidade destas relações de produção constitui a estrutura econômica da sociedade, a base real sobre a qual se eleva uma superestrutura jurídica e política e à qual correspondem formas sociais determinadas de consciência. $\mathrm{O}$ modo de produção da vida material condiciona $\mathrm{o}$ processo de vida intelectual, político e social" (MARX, 2009. p. 47).

${ }^{8}$ Veja-se o que diz sobre Lutero e Smith: "quando o Lutero da economia, Adam Smith, fez a crítica da economia anterior, muito já mudara. O século humanizara-se, a razão soubera impor-se, a moral começava a fazer valer seu direito eterno" (ENGELS, 1979, p. 5). Depois, diz sobre a correlação entre protestantismo, catolicismo e economia política: "a hipocrisia protestante substituiu a franqueza católica. Smith demonstrou que a humanidade também encontrava seu fundamento na essência do comercio e que este, 'em vez de ser a maior fonte de discórdia e hostilidade', deveria tornar-se 'um ponto de harmonia e amizade quer entre as nações, quer entre os indivíduos' (Wealth of nations, liv. 4, cap. 3, § 2)" (ENGELS, 1979, p. 5). Aqui não podemos tratar do assunto, mas vale destacar que essa correlação entre protestantismo e catolicismo está presente tanto na filosofia da religião de Hegel quanto nas teorizações marxianas da mesma época. Para Engels, já em 1844, tais temas são essenciais, e remetem à crítica da economia política.
} 
no Estado. Antes, a própria organização das relações econômicas da sociedade, inerentemente, o faria. As oposições que marcariam a sociedade civil-burguesa seriam apreendidas (e naturalizadas) pela economia política, e, desse modo, seria possível dizer que o funcionamento normal desta sociedade passa pelo "confronto de capital contra capital, de trabalho contra trabalho, de propriedade contra propriedade", o qual "lança a produção num ardor febril que subverte completamente todas as relações naturais e razoáveis" (ENGELS, 1979, p. 16). Engels, assim, passa a procurar não mais o "Estado político" de Hegel e dos neohegelianos, mas a crítica da economia política e de seus pressupostos, que seriam os da moderna sociedade civil-burguesa e trariam em seu bojo a propriedade privada.

O modo pelo qual Engels se coloca diante da antieticidade, portanto, explicita sua posição sobre a correlação entre crítica à religião, à política e à economia política.

Porém, tem-se mais que isso: segundo nosso autor, ao mesmo tempo em que a economia política traz certa potência desagregadora, ela teria consigo também o germe de uma forma superior de sociabilidade, colocada a partir da supressão da propriedade privada, do comunismo. E, assim, é inimaginável se tratar da política, da religião e da economia sem ter em conta esses aspectos, todos, correlacionados. Tal imanência da crítica engelsiana é pungente na época e remete à sua posição sobre Smith. Após destacar o caráter desagregador da economia política e de seus pressupostos, diz nosso autor:

\begin{abstract}
Mas o sistema de Smith não foi um progresso? Certamente que sim e, até mesmo, foi um progresso necessário. Era necessário que o sistema mercantilista, com seus monopólios e seus entraves à circulação, fosse subvertido para que aparecessem claras as verdadeiras consequências da propriedade privada; era necessário que todas as mesquinhas considerações locais e regionais passassem a segundo plano para que a luta do nosso tempo se tornasse universal e humana; era necessário que a teoria da propriedade privada abandonasse o puro empirismo, com suas pesquisas unicamente objetivas, para assumir caráter mais científico, que a tornasse igualmente responsável pelas suas resultantes e deslocasse a coisa para um campo humano em geral, onde a antieticidade ${ }^{9}$ contida na velha economia fosse conduzida à sua expressão mais elevada em razão da sua negação e da hipocrisia que necessariamente decorre da tentativa de negá-la. Tudo isto faz parte da natureza do processo. (ENGELS, 1979, p. 3).
\end{abstract}

Tem-se um processo pelo qual se explicitam tanto as limitações da economia política quanto da sociedade civil-burguesa. A teoria de Smith traria consigo, de um lado, a antieticidade, responsável pala desagregação da família, da sociedade e da esfera pública; doutro, a possibilidade de uma forma de luta, universal e humana, que pudesse trazer a

\footnotetext{
${ }^{9}$ No original, imoralidade. Modificamos dado que a tradução de Unsittlichkeit remete à Sittlichkeit (eticidade), e não à Moralitat (moralidade).
} 
supressão da propriedade privada. O desenvolvimento da economia política e de seus pressupostos poderia levar a sua própria negação, portanto.

O sistema de Adam Smith, assim, seria um enorme progresso. Tal qual Lutero teria trazido avanços para a teologia — que remete mais diretamente à imanência das relações humanas depois da reforma protestante - , algo similar teria se dado com o autor da Riqueza das nações. E, assim, os embates da teologia, bem como aquelas da política (que se colocavam em sua forma mais desenvolvida na filosofia alemã e nos socialistas franceses) teriam sua verdadeira resolução na crítica da economia política e na supressão de seus pressupostos objetivos. A natureza do progresso que vem com tal ausência de ilusões quanto à sociedade calcada na propriedade privada é tal que seria necessário considerar de modo sério a superação das oposições que marcam a sociedade civil-burguesa, não mais no campo da política, da especulação e do direito, mas pela supressão efetiva da própria propriedade privada, do comércio, do monopólio, etc.

Uma crítica da economia política seria possível e necessária porque esta ciência exprimiria as categorias da própria realidade, sendo de uma hipocrisia enorme negar não só os avanços trazidos por ela mas também o caráter desagregador da sociedade civil-burguesa.

Ao remeter à correlação entre crítica à religião, à política e à economia política, nosso autor procura trazer esse aspecto à tona a partir da imanência das formações ideais e da sociedade que ele trata. Com isso, procura demonstrar que a sociedade civil-burguesa traz em seu bojo, não só a antieticidade, mas também a possibilidade de uma outra correlação entre família, sociedade e esfera pública, possibilidade esta calcada na supressão da propriedade privada. Ou seja, trata-se já de uma posição explicitamente socialista.

Isso, por sua vez, já estaria se explicitando na própria realidade da época e, em determinados aspectos, seria possível "recorrer às obras de Fourier" (ENGELS, 1979, p. 15), sendo preciso superar o egoísmo da concorrência com formas de "emulação fundada na própria natureza do homem e que até o momento só foi desenvolvida de modo aceitável por Fourier" (ENGELS, 1979, p. 15-16). A crítica da economia política, portanto, seria necessária porque a posição socialista estaria aparecendo como uma opção viável, de um lado, diante da crescente desonestidade desta ciência ${ }^{10}$, e doutro, diante da antieticidade evidente ${ }^{11}$ que marcava a sociedade da época, analisada e aceita pela economia política.

\footnotetext{
${ }^{10}$ De acordo com nosso autor, tem-se uma situação em que "quanto mais os economistas se aproximam do presente, mais se afastam da honestidade. Quanto mais o tempo avança, mais os sofismas necessariamente aumentam. É por isto, por exemplo, que Ricardo é mais culpado que Adam Smith, e Mac Culloch e Mill mais culpados que Ricardo" (ENGELS, 1979, p. 4).
} 
A exposição engelsiana, desse modo, procura trazer à tona a efetividade das categorias da economia política. E, ao explicitar a natureza das oposições que a marcam, remete ao próprio socialismo. Para isto, porém, tem-se um procedimento que torna o texto de difícil compreensão para o leitor não situado nos debates da época: Engels adentra nos embates utilizando-se das categorias de seus adversários e daqueles que vêm desenvolvendo uma posição contrária a eles. Isto é realizado porque o autor acredita que são essas as categorias que estão presentes de modo mais ou menos mediado na própria realidade; e, assim, formulações - como aquela acerca da teoria do valor, ou da força de trabalho — ainda são estranhas ao Esboço. Categorias de diversos autores aparecem na exposição engelsiana de modo que a própria posição dele, por vezes, não é de fácil apreensão. Se é verdade que ele estava influenciado por pensadores distintos, igualmente verdade é que uma crítica da economia política, bem como o modo pelo qual Engels passa pelas categorias utilizadas por estes pensadores é bastante sui generis.

Desse modo, critica a economia política a partir do desenvolvimento imanente das próprias categorias de Smith, Ricardo, Malthus; Engels remete à crítica à religião apoiando-se explicitamente e de modo elogioso a Feuerbach; traz posições socialistas ao chamar ao texto alguém como Fourier. Ou seja, em um texto em que nosso autor está se colocando sobre os próprios pés, em que sua própria posição se delineia, Engels dá crédito a autores críticos de Hegel em sua crítica à religião, remetendo a Feuerbach, assim como destaca a importância dos socialistas para a oposição à efetividade da economia política. Porém, aquilo que está colocado no texto engelsiano não é um amálgama entre socialistas franceses, economia política inglesa e filosofia clássica alemã. ${ }^{12}$ Antes, tem-se o desenvolvimento da posição do próprio Engels, mesmo que o autor não tivesse a clareza necessária sobre isto na época. E isto deve ser destacado.

O caráter imanente da exposição engelsiana, portanto, tem um aspecto dúplice: de um lado, ele explicita a interrelação e a indissociabilidade entre as diversas esferas do ser social, as formas ideológicas a elas relacionadas e a base material da sociedade. A inseparabilidade

\footnotetext{
${ }^{11}$ Diz Engels que "depois de a economia liberal ter feito tudo para universalizar a hostilidade decompondo as nacionalidades, transformando a humanidade numa horda de bestas ferozes (acaso não são bestas ferozes os que se dedicam à concorrência?) que se entredevoram precisamente porque cada um partilha com todos os outros dos mesmos interesses - após este trabalho preliminar, restava-lhe apenas um passo para chegar ao fim: dissolver a família. Para isso, o sistema fabril, sua bela invenção pessoal, correu em seu auxílio. O último traço dos interesses comuns, a comunidade familiar de bens, foi minada pelo sistema fabril e - pelo menos aqui, na Inglaterra - está a ponto de ser dissolvida" (ENGELS, 1979, p. 6).

${ }^{12}$ A crítica ao amálgama originário que formaria a obra de Marx foi bastante desenvolvida por José Chasin (2009). De nosso ponto de vista, seria preciso trazer com cuidado tal aspecto à análise da obra de Engels.
} 
entre a crítica da religião, da filosofia, da política e da economia política é marcante no texto. Porém, doutro lado, isso se dá muitas vezes sem que se saiba ao certo a diferença específica da posição engelsiana frente àquela de seus opositores e daqueles em quem ele se baseia. Nesse sentido, muitos poderiam inadvertidamente trazer à tona a aderência de Engels ao comunismo filosófico de Hess, ao socialismo de Fourier, à filosofia de Feuerbach. Porém, uma análise séria de seu texto já se depara com o ineditismo de sua empreitada, uma crítica à economia política. Depois, precisa lidar com as determinações das próprias posições do autor, que não se identificam, seja com aquelas daqueles que critica, seja com as dos autores em que se baseia em alguns aspectos.

O Esboço de uma crítica da economia política é um monumento seminal na história do marxismo, sendo preciso estudá-lo com o mesmo afinco com o qual foram analisadas obras como Sobre a questão judaica e os Manuscritos econômico-filosóficos, de Marx. Todos esses textos são marcados por embates com autores neo-hegelianos, socialistas e da economia política (dentre outros aspectos). Como não podemos tratar aqui desses textos de Marx, destacamos que a imanência da exposição engelsiana salta aos olhos. E, com ela, apresenta-se, ao mesmo tempo, de um lado, a crítica à totalidade das relações sociais de uma época, e, portanto, a inseparabilidade entre política, religião, filosofia, economia; doutro, tem-se certa dificuldade de identificar com precisão o solo no qual a posição engelsiana se finca. E, por isso, o texto de Engels cujos muitos meandros não pudemos expor aqui — isso demandaria um espaço que não se dispõe em um só artigo — é de dificílima compreensão, o que não gera o melhor dos cenários para um autor que acredita que a luta de seu tempo adquire uma amplitude universal e humana.

\section{EXPOSIÇÃO E PESQUISA DIANTE DOS EMBATES NA IMPRENSA PERIÓDICA E NO MOVIMENTO DOS TRABALHADORES}

Com a morte de Marx em 1883, e em um cenário em que o movimento socialista crescia, o modo pelo qual se desenvolve a posição engelsiana é um tanto quanto distinto. Se o Esboço denota a pretensão futura de uma crítica da economia política levada até as últimas consequências, nosso autor diz mais para o final de sua vida: "em consequência da divisão de trabalho existente entre Marx e eu, coube-me defender nossos pontos de vista na imprensa periódica, particularmente na luta contra opiniões adversárias, para que Marx tivesse tempo necessário para elaborar sua grande obra” (ENGELS, 1988, p. 8). Em verdade, a grande obra marxiana, O capital, tem como subtítulo justamente "crítica da economia política". Ou seja, a 
pretensão engelsiana acabou por ser realizada por Marx.

Nosso autor, mesmo que tenha contribuído substancialmente com os pontos de vista comuns a ele e a Marx, deixa para o autor de $O$ capital o desenvolvimento substancial daquilo que havia sido colocado como essencial no Esboço. A divisão do trabalho a que remete Engels faz com que a crítica imanente à economia política seja levada a cabo por seu melhor amigo, tendo-se a defesa das grandes descobertas de Marx ficado sob responsabilidade do autor do Anti-Düring. Ou seja, a análise dos pressupostos da sociedade civil-burguesa veio a ficar enfocada em um, enquanto a divulgação da crítica a estes pressupostos, seja na imprensa periódica, seja no seio do movimento socialista, ficou mais próxima doutro. Não há uma muralha chinesa entre os autores (basta pensar que foi justamente Engels a publicar, após ter trabalhado o material, o livro II e o livro III de $O$ capital), que desenvolveram suas concepções em conjunto; porém, as diferentes abordagens são visíveis, e vêm a ter influência no modo de exposição de seus textos.

O título daquela que ficou conhecida como a grande obra engelsiana já é sugestivo: o tom polêmico e contraposto a um autor que seria um ilustre desconhecido, Düring, se não fosse o próprio Engels, tem um significado grande para nosso tema. $\mathrm{O}$ modo pelo qual o autor se coloca depende muito da reafirmação dos seus pontos de vista e dos de Marx diante de autores que são considerados socialistas vulgares, como Düring, Menger, dentre outros. Ou seja, nosso autor marca suas posições a cada momento, não desenvolvendo-as tanto a partir da imanência da sociedade civil-burguesa (embora, claro, faça isso também) mas em oposição a colocações equivocadas de seus antagonistas.

Menger trata muito do Direito, por exemplo. Engels, desse modo, põe-se a abordar tal esfera do ser social, contrapondo-se ao autor; Düring, por sua vez, aborda os mais diversos temas separadamente, de modo sistemático. E, com isso, o autor do Anti-Düring vê-se forçado a seguir a mesma divisão temática, embora, claro, de modo não esquemático e dogmático. $\mathrm{Ou}$ seja, em parte, a exposição engelsiana vem a ser ditada pelo modo de apresentação daqueles que combate. A economia política clássica trazia certa correlação íntima e orgânica entre as diferentes esferas que abordava; no Esboço, Engels radicalizou tal procedimento explicitando a dependência das esferas do ser social e mostrando como que o Estado, a política, a religião não seriam o sujeito desse processo, mas o predicado. Agora, em textos como o Anti-Düring, Socialismo jurídico, A questão da moradia, nosso autor se contrapõe a uma abordagem segmentada, sendo obrigado a criticar as limitações de tal tratamento a partir daquilo que desenvolveu juntamente com Marx. Assim, a pequena envergadura dos adversários faz com 
que seja necessário afirmar os pontos de partida mais básicos, como a determinação da vida dos homens a partir de suas condições materiais de existência, como a correlação entre desenvolvimento das forças produtivas e relações de produção, etc. Engels é obrigado a ser mais sistemático e a reafirmar os princípios de sua análise materialista devido às limitações da própria obra daqueles que ataca e contra quem se coloca em meio ao movimento dos trabalhadores.

Há, porém, outro aspecto importante que precisa ser destacado: no final do século XIX o movimento socialista ganha força e expressão, tendo-se certo ímpeto de popularização da concepção materialista da história por parte de Engels. Sua exposição, assim, marca posição diante dos trabalhadores e do movimento socialista, contrapondo-se teórica e praticamente a certos líderes socialistas e aos rumos do partido social-democrata alemão (SARTORI, 2018a, 2018b). Ou seja, a exposição de nosso autor modifica-se tanto devido ao modo de apresentação daqueles a que se contrapõe quanto devido a uma motivação de popularizar aquilo que se tornaria, mais tarde, o marxismo.

Neste ímpeto, por vezes, Engels deixa de ser tão claro quanto à necessidade de uma crítica da economia política, por exemplo: "a economia política como a ciência das condições e das formas, sob as quais as diferentes sociedades humanas produziram e trocaram", e continua nosso autor: "e sob as quais, em cada caso, distribuíram os produtos de modo correspondente - a economia política com esta amplitude ainda está para ser criada" (ENGELS, 2015, p. 181). Assim, parece ser possível desenvolver uma outra economia política, deixando de ser necessária uma efetiva crítica da economia política, como ele, em seu Esboço, e depois Marx em O capital, preconizaram. A concepção engelsiana de economia política - até certo ponto, com a concordância de Marx, que leu o Anti-Düring e até mesmo contribui na escrita de algumas partes desta obra — torna-se diferente daquela de 1844 e daquela da obra marxiana. Isso talvez se dê devido aos meandros expositivos que levantamos acima. Porém, há de se dizer que isso tem uma grande influência no modo pelo qual a concepção materialista da história se populariza, de certo modo e em determinada medida, sem uma crítica resoluta à economia política.

Isso se dá somente em parte, claro. O próprio Engels dedicou muito de seu tempo à publicação da obra de Marx cujo título é justamente "crítica da economia política". Mas é preciso destacar: de um lado, passa-se a ter $O$ capital, cuja leitura nem sempre é das mais leves; doutro, os textos de divulgação do autor de Do socialismo utópico ao socialismo científico. Certamente não há uma oposição estanque entre as duas abordagens, porém, há 
diferenças substantivas na exposição e na recepção das obras. E, com isso, a empreitada da crítica da economia política pôde ficar eclipsada por um tempo.

\section{DA CRÍTICA À ECONOMIA POLÍTICA À CRÍTICA AO DIREITO: A CONFORMAÇÃO DA LUTA SOCIALISTA NO ÚLTIMO ENGELS}

Neste cenário, Engels sempre afirmou a necessidade de ir às raízes econômicas dos fenômenos sociais, criticando aqueles que partiam, por exemplo, do Direito: ao atacar os que se apegam ao terreno do direito, diz nosso autor que "quando nosso homem do direito se firma no próprio terreno jurídico, despreza a história econômica" (ENGELS; KAUTSKY, 2012, p. 24). Seria preciso, assim, reafirmar as descobertas de Marx diante de um movimento socialista que tendia a permanecer no âmbito jurídico. A afirmação da ciência, desse modo, seria essencial para que o socialismo pudesse se colocar como uma força material perante as massas. Diz Engels (2015, p. 56) que "devemos a Marx estas duas grandes descobertas: a concepção materialista da história e a revelação do mistério da produção capitalista mediante o mais-valor." No que continua explicitando que "elas fizeram do socialismo uma ciência que agora deve, em primeiro lugar, continuar a ser elaborada em todos os seus pormenores e em todas as suas conexões." De um lado, nosso autor vê-se impelido a desenvolver e elaborar as conexões trazidas pelas descobertas de Marx; doutro, em meio a um movimento socialista intelectualmente débil, é forçado a reafirmar justamente as descobertas das quais seria preciso partir.

Para abrir o caminho para a efetiva crítica às condições materiais de existência dos homens concretos, precisou-se, portanto, atacar os pontos de partida, como o jurídico, que eram tomados como corretos pelos homens colocados na situação em que as conquistas de concessões jurídicas pareciam poder levar o movimento dos trabalhadores àquilo que, mais tarde, foi chamado por Bernstein (um discípulo de Engels até certo ponto, diga-se de passagem) de socialismo evolucionário (BERNSTEIN, 1997). E, nesse contexto, a crítica ao Direito vem a ganhar espaço na obra engelsiana. Nunca se deixou de lado a crítica à economia política, atacando-se sempre a valorização do valor, bem como a anatomia da economia burguesa. Porém, o enfoque imediato de Engels veio a ser outro. Em crítica a certas concepções socialistas que não tinha consigo a crítica do valor, diz nosso autor algo que mostra esse seu ímpeto de crítica à economia política:

Querer abolir a forma de produção capitalista mediante a instituição do 'valor verdadeiro' significa, por conseguinte, querer abolir o catolicismo mediante a 
instituição do 'verdadeiro' papa ou querer instituir uma sociedade em que os produtores finalmente dominariam seu produto mediante a execução consequente de uma categoria econômica, que é a expressão mais abrangente da escravização do produtor por seu próprio produto. (ENGELS, 2015, p. 344).

Engels é muito claro quanto à necessidade de uma crítica às categorias da economia política, como o valor. Com isso, inclusive, remete à correlação entre a crítica à religião e a crítica à economia política ${ }^{13}$. Assim como não seria possível uma verdadeira crítica ao catolicismo sem criticar o papa, não se poderia superar o capitalismo sem remeter à supressão do valor. Ou seja, a teorização sobre, bem como a crítica à economia política não é ausente em Engels; antes, tem um papel central. Porém, como dissemos, ela é levada a um patamar não tão explícito em termos expositivos e, com isso, permanece como uma espécie de pressuposto de nosso autor, correlacionado à concepção materialista da história e à compreensão do mais-valor. Ou seja, tem-se elementos importantes da posição de nosso autor. Porém, eles nem sempre vêm a primeiro plano em suas polêmicas.

Há, porém, outro motivo importante para isso: as lutas práticas do movimento dos trabalhadores estavam avançando nas instituições burguesas (HOBSBAWM, 2007). Isto fazia com que as conquistas de concessões por parte dos socialistas estivessem no ar, ${ }^{14}$ o que, mesmo não fosse o essencial, seria central na organização da tática e da estratégia socialistas. Depois da Comuna de Paris, ter-se-ia uma condição em que, ao mesmo tempo, ter-se-ia conquistas de direitos e a necessidade da crítica ao Estado. Ou seja, novamente, tal qual na década de 1840, seria importante a crítica à política e ao Direito. Porém, agora a coisa seria diferente, já que os trabalhadores estariam na ofensiva.

A França naturalmente precisou de muitos anos para recuperar-se da sangria de maio de 1871. Na Alemanha, em contraposição, onde se desenvolvia cada vez mais rapidamente a indústria, cultivada em condições ideais de estufa e, como se não bastasse, abençoada com o aporte bilionário recebido da França, cresceu com

\footnotetext{
${ }^{13}$ Veja-se Engels quanto às origens da religião e a correlação dela com a ausência de controle consciente das condições de vida: "toda a religião nada mais é que o reflexo fantástico, na mente dos seres humanos, daquelas potências exteriores que dominam sua existência cotidiana, um reflexo no qual as potências terrenas assumem a forma de potências sobrenaturais. Nos primórdios da história, quem primeiro experimenta esse reflexo são as potências da natureza e, no desenvolvimento ulterior, elas passam, entre os diferentes povos, pelas mais multifacetadas e variegadas personificações. Esse primeiro processo foi retraçado, ao menos no tocante aos povos indo-europeus, pela mitologia comparativa, até sua origem nos Vedas indianos, sendo que a sua evolução foi comprovada detalhadamente entre os hindus, persas, gregos, romanos, germanos e, na medida em que há material suficiente, também entre os celtas, lituanos e eslavos. Porém, logo passam a atuar, ao lado das potências naturais, potências sociais - potências tão estranhas e de começo tão inexplicáveis para os seres humanos que os dominavam com a mesma aparente necessidade natural das próprias potências da natureza. Os vultos fantásticos, nos quais se refletiam de começo apenas as forças misteriosas da natureza adquirem desse modo atributos sociais, tornando-se representantes de potências históricas" (ENGELS, 2015, p. 349-350).

${ }^{14}$ Para uma análise destas conquistas de concessões: Sartori (2019).
} 
rapidez e solidez ainda maiores a socialdemocracia. Graças à sabedoria com que os trabalhadores alemães utilizaram o direito de voto universal introduzido em 1866, o crescimento espantoso do partido apresenta-se aos olhos do mundo em números incontestáveis. Em 1871: 102 mil; em 1874: 352 mil; em 1877: 493 mil votos socialdemocratas. Em seguida, veio o alto reconhecimento desses progressos por parte da autoridade na forma da Lei de Exceção contra os Socialistas; o partido se dispersou momentaneamente, o número de votos despencou para 312 mil em 1881. Porém, isso foi rapidamente superado, e agora, sob a pressão da lei de exceção, sem imprensa, sem organização exterior, sem direito de associação nem de reunião, foi que começou para valer a rápida expansão - em 1884: 550 mil; em 1887: 763 mil; em 1890: 1,427 milhão de votos. Diante disso, a mão do Estado ficou paralisada. A Lei contra os Socialistas sumiu, o número de votos socialistas subiu para 1,787 milhão, mais de um quarto de todos os votos depositados. O governo e as classes dominantes haviam esgotado todos os seus recursos - inutilmente, em vão, sem êxito. As provas palpáveis de impotência que as autoridades, desde o guarda noturno até o chanceler do Reich, tiveram de engolir - e isso dos desprezados trabalhadores! -, essas provas atingiam a cifra de milhões. O Estado já não tinha mais o que dizer, os trabalhadores estavam apenas começando a falar. (ENGELS, 2012, p. 20).

A comuna tem um papel essencial na teorização engelsiana. A partir dela, depois de determinado momento, pensa-se, inclusive, na peculiaridade de cada formação social, como a francesa e a alemã. Com isso, seria preciso destacar que as condições ideais nas quais teria se desenvolvido a socialdemocracia alemã seriam um resultado contraditório tanto das condições sui generis do país quanto da situação mundial. Esta última estaria marcada por conflitos entre países capitalistas e, posteriormente, pela projeção e pela derrota da Comuna de Paris. Desse modo, o direito ao voto, por si, não seria o essencial. O uso que os trabalhadores alemães conseguiram fazer dele, por outro lado, teria sido central para que o movimento socialista, expresso no crescimento do partido da socialdemocracia, tivesse proeminência. Percebe-se que há um aspecto bastante dúplice nisto: por meio da conquista de um direito, teve-se o crescimento e o desenvolvimento do potencial de questionamento ao modo capitalista de produção. Segundo nosso autor, porém, as ilusões que advieram dessa condição não teriam sido poucas.

Daí ser essencial uma crítica ao Direito. Engels, assim, procura demonstrar como que não se poderia fetichizar o direito ao voto; os números do partido seriam incontestáveis, porém o reconhecimento dos trunfos do movimento dos trabalhadores não viria só no incremento nos votos, mas em algo aparentemente incompatível com isto, uma lei de exceção. Não haveria qualquer caminho progressivo pelas instituições, portanto. Antes, nota-se que ocorreria o oposto: a supressão da imprensa livre e do direito de reunião, bem como a persecução aos socialistas seriam o caminho mais lógico no terreno do Direito, que, com isso, passa a outro patamar, que é seu desenvolvimento burguês na sociedade capitalista, aquele da 
contrarrevolução ${ }^{15}$. Ou seja, por vezes, em meio ao próprio uso do terreno do Direito, e do direito ao voto, os trabalhadores acabam levando a burguesia à contrarrevolução e a colocarse diante da própria legalidade de modo dúbio: "violar pessoalmente essa legalidade que lhes é tão fatal" (ENGELS, 2012, p. 22). A própria legalidade passa a ser um entrave ao domínio burguês em algumas circunstâncias, portanto. E a continuidade dos avanços, por parte dos trabalhadores, e neste terreno, depende justamente de que isso não ocorra. Caso aquilo estipulado na lei e nas instituições burguesas afronte o domínio burguês, esta classe não tarda a abandonar seus ideais primevos, colocando-se explicitamente a favor de medidas de terror classista.

Ou seja, não se tem um caminho evolucionário ao socialismo; a evolução normal do Estado e do Direito está dada, não em sua ampliação para as classes populares, mas no modo pelo qual, havendo essa expansão do terreno, ele pode negar a si mesmo.

A crítica ao Direito seria necessária, portanto. Isto ocorre porque o avanço na conquista de direitos não garantiria um caminho para avanços progressivos. $\mathrm{O}$ grande ganho desse confronto no terreno legal estaria, de um lado, no esgotamento dos recursos normais das classes dominantes e na impotência das autoridades constituídas e, doutro, no fato de os trabalhadores estarem começando a se colocar de modo mais decidido na esfera pública. E isto, não só na medida em que aumenta a projeção eleitoral do partido socialdemocrata, mas principalmente porque o Estado não teria mais o que dizer. A participação eleitoral e a conquista de direitos, dessa maneira, redundam na crítica ao Estado e ao Direito. E, em verdade, as possibilidades presentes no direito ao voto e na participação no Estado e no terreno do Direito sequer poderiam ser universalizadas:

Os trabalhadores revolucionários dos países românicos haviam se acostumado a ver o direito de voto como uma armadilha, como um instrumento do governo para fraudá-los. Na Alemanha era diferente. O Manifesto Comunista já havia proclamado a conquista do direito de voto universal, da democracia, como uma das primeiras e mais importantes tarefas do proletariado militante, e Lassalle retomara esse ponto. (ENGELS, 2012, p. 20-21).

Segundo Engels, tais possibilidades seriam, até certo ponto, uma especificidade alemã. Nos países românicos, não raro, ter-se-ia o voto fraudado e uma armadilha colocada no direito ao voto. Na Alemanha, por outro lado, a conquista do voto universal, da democracia, como se

\footnotetext{
${ }^{15}$ Marx diz na Nova Gazeta renana que "jamais o escondemos. Nosso terreno não é o terreno do direito, é o terreno revolucionário. $\mathrm{O}$ governo agora acaba de abandonar, por sua vez, a hipocrisia do terreno do direito. Colocou-se sobre o terreno revolucionário, pois também o terreno contrarrevolucionário é revolucionário" (MARX, 2010, p. 318). Para uma análise da questão, ver Cotrim (2010).
} 
coloca no Manifesto, seria essencial para o proletariado.

Ou seja, a crítica ao Direito e a crítica ao Estado seriam essenciais no contexto alemão - basta pensar na crítica marxiana ao programa de Gotha e a Lassale (MARX, 2012b) justamente porque as disputas classistas que giram em torno do Estado e do Direito teriam possibilidades (as quais não necessariamente seriam desenvolvidas) que poderiam levar a classe trabalhadora do terreno do Direito ao terreno revolucionário. Nesse sentido, o enfoque engelsiano na crítica ao Direito não denota uma posição de abandono da crítica da economia política e da economia capitalista; antes, ela significa que nosso autor procurou sempre explicitar a diferença específica de uma crítica ao modo de produção capitalista como tal diante do ataque somente aos sintomas deste sistema social. Assim, Engels vê-se obrigado a realizar uma tarefa importante: marcar, a partir de uma crítica ao Direito e ao Estado, as limitações, e as possibilidades, desses terrenos. Enquanto Marx realiza a crítica da economia política de modo mais cuidadoso em $O$ capital, o tom de Engels é bastante polêmico diante do movimento dos trabalhadores e dos socialistas.

Para reafirmar as bases de uma crítica da economia política - a crítica, não só ao capitalismo, mas ao valor - nosso autor precisa questionar o Direito e a atuação no campo estatal. O autor do Anti-Düring diz sobre o direito ao voto:

\begin{abstract}
E se o direito de voto universal não tivesse proporcionado nenhum outro ganho além de permitir-nos contar todos a cada três anos; de, junto com o aumento regularmente constatado e inesperadamente rápido do número de votos, aumentar na mesma proporção a certeza da vitória dos trabalhadores assim como o susto dos adversários, e assim tornar-se o nosso melhor meio de propaganda; de instruir-nos com exatidão sobre as nossas próprias forças, assim como sobre as de todos os partidos adversários, e de, por essa via, fornecer-nos um parâmetro inigualável para dar à nossa ação a proporção correta - preservar-nos tanto do temor inoportuno quanto do destemor inoportuno - , se esse fosse o único ganho que tivéssemos obtido do direito de voto, já teria valido a pena. Mas ele trouxe muito mais que isso. Durante a campanha eleitoral, ele nos forneceu um meio sem igual para entrar em contato com as massas populares onde elas ainda estão distantes de nós e obrigar todos os partidos a defender-se diante de todo o povo dos nossos ataques às suas opiniões e ações; e, além disso, ele colocou à disposição dos nossos representantes uma tribuna no Parlamento, do alto da qual podiam dirigir a palavra tanto a seus adversários no Parlamento como às massas do lado de fora com muito mais autoridade e liberdade do que quando falam para a imprensa ou em reuniões. De que serviam ao governo e à burguesia a sua Lei Contra os Socialistas, se a campanha eleitoral e os discursos socialistas no Parlamento a violavam continuamente? (ENGELS, 2012, p. 21-22).
\end{abstract}

O direito ao voto permitiria que se exercesse propaganda. O enfoque, portanto, não estaria tanto em ganhar as eleições, mas inundar a esfera pública com o pensamento e com a prática socialistas. $\mathrm{O}$ contato com as massas populares seria o essencial. E, desse modo, longe 
de Engels estar valorizando o terreno do Direito por ele relacionar-se com o Estado, tem-se o oposto. Trata-se de utilizar-se do direito ao voto para que, com a propaganda socialista, seja possível um salto qualitativo ao terreno revolucionário.

Trata-se, assim, da conscientização das massas, bem como de colocar os outros partidos na defensiva diante do avanço do movimento dos trabalhadores. A palavra dos socialistas, portanto, seria dirigida aos adversários no parlamento; porém, não só. Seria preciso voltar-se às massas do lado de fora. Ou seja, somente seria possível atuar coerentemente na esfera pública ao se realizar uma crítica ao Estado e ao Direito. Mesmo que envolvidos em órgãos de Estado, e mesmo que tendo conquistado o direito ao voto, tratar-seia de um movimento político que só pode avançar ao criticar teórica e praticamente as limitações do Estado. Assim, a lei contra os socialistas seria violada constantemente tanto no parlamento quanto fora dele, não sendo o objetivo engelsiano a legalização da atuação socialista, mas o avanço na propaganda e na crítica à sociedade capitalista. Os direitos ao voto, à imprensa livre, à reunião, etc. não seriam, portanto, algo com valor por si mesmo. E, portanto, a atuação ilegal da classe trabalhadora não necessariamente seria um grande problema. Dependeria bastante das circunstâncias se a legalidade ou a ilegalidade seriam adequadas ao avanço do campo socialista. Aqui, portanto, Engels explicita como que o essencial não está no terreno do Direito. Seria, porém, possível uma atuação que passasse por esse terreno? Como vimos, isso seria até mesmo necessário. Porém, é preciso que se mostrem com mais cuidado os detalhes da coisa:

\begin{abstract}
Esse uso bem-sucedido do direito de voto universal efetivou um modo de luta bem novo do proletariado e ele foi rapidamente aprimorado. O proletariado descobriu que as instituições do Estado, nas quais se organiza o domínio da burguesia, admitem ainda outros manuseios com os quais a classe trabalhadora pode combatê-las. Ele participou das eleições para as assembleias estaduais, para os conselhos comunais, para as cortes profissionais, disputando com a burguesia cada posto em cuja ocupação uma parcela suficiente do proletariado tinha direito à manifestação. E assim ocorreu que a burguesia e o governo passaram a temer mais a ação legal que a ilegal do partido dos trabalhadores, a temer mais os sucessos da eleição que os da rebelião. (ENGELS, 2012, p. 22).
\end{abstract}

As instituições do Estado são próprias ao domínio burguês; Engels é explícito sobre isto. Por esse motivo, não se pode deixar de lado uma crítica ao Estado. Porém, os outros manuseios dessas instituições por parte da classe trabalhadora seriam necessários.

Não que nosso autor acredite que, com isso, muda-se a essência e a especificidade do Estado; isto passa longe de ocorrer. Porém, as disputas que se dão no Estado levariam o 
proletariado a se manifestar, a se colocar de modo proeminente na esfera pública. E o cenário em que isso se dá seria aquele em que "o Estado já não tinha mais o que dizer, os trabalhadores estavam apenas começando a falar" (ENGELS, 2012, p. 20). A manifestação aberta do proletariado seria importantíssima; os espaços ocupados no Estado seriam relevantes para tal. Porém, ao mesmo tempo, seria essencial que a atividade do movimento socialista fosse exercida com a crítica ao Direito e ao Estado.

A razão pela qual a burguesia temeria a atuação legal do proletariado, portanto, não se liga tanto ao fato de esta classe, por vezes, ganhar as eleições. Mas ao fato de a manifestação incisiva do proletariado organizado poder chegar às massas. Os sucessos na eleição não seriam tanto aqueles da posse do aparato estatal por via do direito ao voto; antes, ter-se-ia a potencialidade de se explicitar a necessidade de uma posição socialista.

A burguesia temeria a atuação legal do proletariado porque, por trás dela, haveria a crítica à própria sociedade capitalista, ao valor, e à existência das classes sociais como tais. $\mathrm{O}$ modo pelo qual se apresenta tal crítica, portanto, passa pelo Estado e pelo Direito, mas não se atém a eles. Por isto, há uma convergência entre a atuação do movimento dos trabalhadores e a crítica ao Direito; a crítica da economia política é um pressuposto para isso. Porém, como vemos, a exposição engelsiana acaba por tomá-la como um ponto de partida a ser assumido e a ser reafirmado, mas não a ser desenvolvimento em seu movimento interno. Se Marx realiza tal empreitada em $O$ capital, Engels está editando os livros II e III desta obra; mas, devido às circunstâncias que já destacamos, acaba por trazer uma exposição muito mais marcada pela crítica ao Direito e ao Estado.

Assim, tem-se uma situação dúplice. No momento em que as barricadas e a rebelião espontânea parecem perder a força e as potencialidades, a luta no aparato estatal também não é resolutiva por si. A burguesia, então, temia tanto a insurreição realizada nos moldes da Comuna de Paris quanto a atuação legal do proletariado. E, segundo Engels, seria preciso tomar de modo bastante crítico as duas experiências. No caso das barricadas, tem-se que as cidades se modificavam e, com isto, "muitas coisas mais se modificaram, e todas favorecendo os militares. Se as grandes cidades se tornaram consideravelmente maiores, proporcionalmente ainda maiores se tornaram os exércitos" (ENGELS, 2012, p. 24). O grande mérito da comuna teria sido sair dessa forma de luta defensiva colocada nas barricadas; assim, diz Engels que os trabalhadores "preferirão o ataque aberto à tática passiva das barricadas, como ocorreu em toda a grande revolução francesa, no dia 4 de setembro e no dia 31 de outubro de 1870 em Paris" (ENGELS, 2012, p. 26). A afirmação da necessidade da luta no 
interior do Estado, portanto, não retiraria de campo a sublevação aberta; antes, haveria convergência entre as duas coisas.

Justamente o preparo das massas por meio da propaganda e da divulgação do socialismo na esfera pública seria central para que uma ofensiva pudesse ser bem-sucedida. Tal ofensiva, portanto, traria consigo a consciência de que a sociedade civil-burguesa e seus pressupostos estão ultrapassados. Ou seja, tem-se como pano de fundo a crítica da economia política. Ao mesmo tempo, porém, um complemento natural dessa crítica está na crítica ao Estado e ao Direito. A luta legal, portanto, seria importante para que se abrisse espaço para a revolução social ${ }^{16}$. Sendo a burguesia levada a violar a sua própria legalidade, ela se coloca no terreno da contrarrevolução e, com isso, há algo bastante peculiar no desenvolvimento das relações sociais da época:

\begin{abstract}
A ironia da história mundial vira tudo de cabeça para baixo. Nós, os "revolucionários", os "sublevadores", medramos muito melhor sob os meios legais do que sob os ilegais e a sublevação. Os partidos da ordem, como eles próprios se chamam, decaem no estado legal criado por eles mesmos. Clamam desesperados, valendo-se das palavras de Odilon Barrot: la légalité nous tue, a legalidade nos mata, ao passo que, sob essa legalidade, ganhamos músculos rijos e faces rosadas e temos a aparência da própria vida eterna. E se nós não formos loucos a ponto de nos deixar levar para as ruas só para agradá-los, acabará não lhes restando outra saída senão violar pessoalmente essa legalidade que lhes é tão fatal. (ENGELS, 2012, p. 22).
\end{abstract}

A ironia a que se refere Engels não tem uma validade universal; ela decorre de circunstâncias específicas e é mais propícia a ocorrer em formações sociais específicas ${ }^{17}$. A tática dos revolucionários passa pelos meios legais; isto, pelo que vemos, não significa que a democracia tenha um valor universal, mas que, por meio dela, a classe trabalhadora pode fazer com que a burguesia afronte a legalidade criada por ela mesma. Engels, na sua crítica às barricadas, que seriam essencialmente defensivas, clama pela sublevação de massa. Mas esta

\footnotetext{
${ }^{16}$ Diz nosso autor que "foi-se o tempo dos ataques de surpresa, das revoluções realizadas por pequenas minorias conscientes à testa de massas sem consciência. Quando se trata de uma remodelagem total da organização social, as próprias massas precisam estar presentes, precisam já ter compreendido o que está em jogo, [pelo que empenham devem empenhar] o corpo e a vida. Isso nos foi ensinado pela história dos últimos cinquenta anos. Longo e persistente, e é justamente esse trabalho que estamos fazendo agora e com um êxito tal que leva os nossos adversários ao desespero" (ENGELS, 2012, p. 26).

${ }^{17}$ A esse respeito, vale ver como Engels compara o voto na França e na Alemanha: "os trabalhadores alemães ainda prestaram à sua causa um segundo grande serviço ao lado do primeiro, que era o de, pelo simples fato de existirem, já se apresentarem como o partido socialista mais forte, mais disciplinado e que mais rapidamente se expandia. Eles haviam mostrado aos colegas de todos os países uma das suas armas mais afiadas, ensinando-lhes como fazer uso do direito de voto universal. O direito de voto universal já existia há muito tempo na França, mas havia adquirido má fama em virtude dos abusos que o governo bonapartista praticara com ele. Depois da Comuna não restou mais nenhum partido de trabalhadores para tirar proveito dele" (ENGELS, 2012b, p. 20). Sobre a especificidade nacional, ver Claudin (2012).
} 
precisaria de preparo. E a ironia da coisa está em este preparo poder se dar nas instituições burguesas. A situação, portanto, é bastante dúbia: para passar do terreno do Direito para o terreno revolucionário - tal qual antes a burguesia havia passado do terreno religioso para o terreno do Direito (ENGELS; KAUTSKY, 2012) - seria preciso, ao mesmo tempo, atuar no campo do inimigo e criticar tal campo com vigor.

Por vezes, isso implicaria em abdicar de ir às ruas. As barricadas não seriam mais a melhor opção, sendo preciso estar preparado para uma manifestação e uma insurreição ofensiva e de massa. Passa-se, assim, de uma situação em que "o Estado já não tinha mais o que dizer, os trabalhadores estavam apenas começando a falar" para aquela em que a atualidade da ofensiva socialista se coloca na ordem do dia. Engels, portanto, passa longe de ter deixado de lado a crítica à sociedade capitalista (que implica a crítica ao valor e, portanto, à economia política); porém, numa época em que o movimento dos trabalhadores consegue avançar nas instituições burguesas, a crítica ao Direito e ao Estado seriam centrais em termos expositivos. Os meandros da coisa são explicitados por Engels porque há duas atitudes que seriam inaceitáveis: de um lado, aquela de uma espécie de bela alma, que não se envolve com a política e com o Direito, que seria o campo da burguesia. Doutro, tem-se a atividade política que não é exercida com o auxílio da crítica ao Estado e ao Direito, que pressupõem justamente a crítica à economia política.

\section{PEGAR A BURGUESIA PELA PALAVRA: ENGELS E A IGUALDADE SOCIAL}

O terreno do Direito seria essencialmente burguês, mas não haveria simplesmente como abandoná-lo à burguesia. Assim como o terreno religioso teria aberto caminho para o jurídico, isto se daria com a correlação entre aquele do Direito e o revolucionário (SARTORI, 2018b). Para que isso pudesse se dar, a crítica ao Direito e a crítica ao Estado seriam essenciais. Porém, enunciar isto não é o mesmo que conseguir realizar tal empreitada. Os esforços de Engels vão no sentido da popularização dessa crítica. No momento em que os trabalhadores começam a se mobilizar e em que o Estado não pode mais oferecer muito a eles, isto seria essencial. Mas, simultaneamente, não seria nada simples.

Para que entendamos isto, é preciso que retomemos algo essencial à obra engelsiana, os meandros de seu modo de exposição. Se isto apareceu acima porque a ênfase de nosso autor traz como pressuposta a crítica da economia política, há de se apontar que poderia ter como consequência certa aparência de autonomização daquilo que definitivamente não é 
autônomo. De um lado, categorias como "igualdade" poderiam parecer — tal qual em Hegel (MARX, 2011) - brotar umas das outras. Da igualdade religiosa, pareceria desenvolver-se a igualdade jurídica e, a partir desta, a econômica e social. Doutro lado, tem-se a ligação entre esferas do ser social sendo explicitadas. Ou seja, a exposição engelsiana leva tanto à popularização da concepção materialista da história quanto à possibilidade de uma leitura parcelada. Mesmo que não seja isso que quer o autor, e mesmo que uma leitura cuidadosa de seus textos não permita tal interpretação, há de se admitir que o modo de exposição de Engels acaba por dar espaço a leituras deformadas de sua posição quanto ao Direito e ao Estado.

Veja-se o que diz o autor sobre a correlação entre burguesia e proletariado diante do ideal de igualdade, bem como da efetividade deste nas distintas classes sociais.

\begin{abstract}
Sabe-se, por outro lado, que a burguesia, desde o instante em que sai do embrião da burguesia feudal, instante em que, de camada feudal se converte em classe moderna, se vê ladeada, sempre e em todas as partes, inseparavelmente, como por sua própria sombra, pelo proletariado. E ao movimento da igualdade burguesa acompanha, também, como a sombra ao corpo, o movimento da igualdade proletária. Desde o instante em que se proclama o postulado burguês da abolição dos privilégios de classe, ergue-se o postulado proletário da abolição das próprias classes, postulado esse que adota primeiro a forma religiosa, baseada no cristianismo primitivo, e que, mais tarde, se apoia nas próprias teorias burguesas da igualdade. Os proletários colhem a burguesia pela palavra: é preciso que a igualdade exista não só na aparência, que não se circunscreva apenas à órbita do Estado, mas que tome corpo e realidade, fazendo-se extensiva à vida social e econômica. E, desde que a burguesia francesa, sobretudo depois da Grande Revolução, passou a considerar em primeiro plano a igualdade burguesa, o proletariado francês coloca, passo a passo, as suas próprias reivindicações, levantando o postulado da igualdade social e econômica, e, a partir dessa época, a igualdade se converte no grito de guerra do proletariado, e, muito especialmente, do proletariado francês. (ENGELS, 1990, p. 89).
\end{abstract}

$\mathrm{Na}$ passagem, tem-se uma correlação entre as classes sociais, as relações econômicas, a religião, o Direito e o questionamento ao modo de produção capitalista. Tal qual no Esboço, isto é presente, mas está muito mais desenvolvido.

Nesse sentido, há avanços evidentes na teorização engelsiana, que se ampara na crítica marxiana à economia política e, com isso, explicita a correlação entre as várias críticas que são necessárias para que se possa superar a situação presente.

Engels, portanto, não é um simples divulgador e simplificador das descobertas de Marx. Porém, sua exposição não deixa de trazer o elemento dúplice que mencionamos. Em meio à situação trazida acima, a conformação das modernas classes sociais, bem como a mobilidade social que isso parece implicar, parece se movimentar nas categorias da igualdade: estas parecem ter um movimento próprio, na forma de igualdade burguesa e de igualdade 
proletária; as oposições de classe parecem estar "suprassumidas", ou seja, negadas, afirmadas e conservadas em um patamar superior no conceito de igualdade.

E, assim, a contradição essencial, por vezes, aparece, não nas categorias e formas econômicas da própria sociedade civil-burguesa, mas em ideias, que, no limite, parecem presidir o real. Por vezes, pode parecer que Engels não conseguiu superar propriamente a dialética hegeliana, visão esta que parece se fortalecer pela sua abordagem, por vezes apressada, da dialética da natureza (LUKÁCS, 2010, 2013). Ou seja, mesmo que isso não ocorra de fato no tema que aqui tratamos, a exposição engelsiana passa certa impressão equivocada segundo a qual, tal qual na lógica hegeliana, as categorias brotam umas das outras (SARTORI, 2014). Ao abordar a igualdade e o Direito em um capítulo do Anti-Düring, abrese espaço para isso; trata-se de uma interpretação equivocada, mas que é propiciada pelo próprio modo de exposição. Ou seja, ao mesmo tempo, não há como dizer que Engels é o culpado por certa abordagem equivocada e não se tem como isentá-lo completamente da responsabilidade pelo ocorrido (SARTORI, 2020).

O fato de a igualdade ter sido um grito de guerra da burguesia (ENGELS; KAUTSKY, 2012) para depois converter-se em uma forma ideológica pela qual o proletariado toma consciência das contradições sociais é destacado por nosso autor, que, assim, não traz uma concepção passiva e rasteira sobre a ideologia. Engels demonstra como que pode haver certa tomada de consciência acerca da necessidade da passagem da igualdade jurídica para a econômica social, ou seja, precisa-se ir do terreno do Direito ao terreno revolucionário. Porém, a exposição de nosso autor mostra que o proletariado pode pegar a burguesia pela palavra a partir da categoria da igualdade; mas somente trata do modo como isso efetivamente pode ocorrer noutros textos, como aqueles que citamos acima e que remetem à correlação entre o direito ao voto, a insurreição, a peculiaridade alemã, as lutas sociais e as lutas por direitos. Ou seja, mesmo que a igualdade burguesa e a proletária não tenham um desenvolvimento autônomo, a exposição engelsiana nem sempre facilita as coisas; se, por um lado, ela deixa claro como que o terreno do Direito é burguês e, portanto, não deixa margem para ilusões quanto à questão, doutro certo tratamento sistemático dos temas (Direito e igualdade, por exemplo) faz com que a correlação entre crítica à economia política, à religião, à política e ao Direito nem sempre fique tão clara quanto deveria. $\mathrm{O}$ tratamento engelsiano também parece se dar em um grau de universalidade bastante grande em alguns momentos. Na passagem que vimos acima, ele utiliza como exemplo no tema da igualdade o proletariado francês, sendo que, noutros momentos, explicita a importância do estudo detido de cada 
formação social.

Vê-se, portanto, que a fórmula engelsiana segundo a qual o proletariado poderia pegar a burguesia pela palavra traz consigo diversos elementos, os quais nem sempre estão claros na primeira mirada. A passagem do terreno do Direito para o terreno revolucionário implica justamente no que Engels destaca na passagem: em algo que passe pelo Direito, mas que remeta para além dele; porém, ao mesmo tempo em que a crítica ao Direito e ao Estado fiquem explícitas na citação acima, o movimento maior, que o próprio Engels explica noutros lugares, fica como um pressuposto. A divulgação, assim, pode ter um efeito bastante grande de popularização; porém, ao mesmo tempo, faz com que, com o modo de exposição adotado, abra-se espaço para mal-entendidos.

Tem-se a explicitação da correlação entre as críticas da economia política, da religião, da política e do Direito. Porém, isto nem sempre fica evidente à primeira vista. E, assim, há um movimento oposto àquele do Esboço: em 1844, esta correlação era vista de modo bastante imanente e explícito, mas a diferença específica diante daqueles com quem Engels debatia não ficava tão clara. No final de sua vida, a diferença específica de uma concepção científica frente a uma acrítica fica evidente - e isso tem uma importância enorme nas lutas dos trabalhadores na época - porém a inter-relação necessária entre diferentes esferas do ser social e críticas específicas a essas esferas corre o risco de ficar eclipsada. O proletariado certamente poderia pegar a burguesia pela palavra, mas isto somente poderia se dar ao se ter em conta todos os elementos que Engels levou ao abordar as barricadas, a época posterior à comuna, as lutas no interior do Estado, a necessidade da crítica ao valor, etc. E, na exposição engelsiana, mesmo que se tenha efetivamente tais ligações, não é sempre que elas ficam plenamente explícitas.

\section{APONTAMENTOS FINAIS}

Notamos que Engels nunca deixa de lado a crítica à economia política. Porém, em um ímpeto de intervir na realidade de seu tempo, e diante de circunstâncias que tornam necessária uma crítica ao Direito e ao Estado, sua exposição traz outro enfoque.

Nele, certamente, há uma correlação íntima entre a crítica à religião, à política, ao Direito e à economia política, tal qual na época do Esboço. Porém, a forma pela qual o autor do Anti-Düring se expressa é mais sistemática, fazendo com que seja preciso visitar vários textos para que fique plenamente clara a correlação entre essas críticas. Isso traz um lado bom 
e um lado mais problemático: ao mesmo tempo em que Engels marca de modo explícito sua posição e a de Marx, reafirmando seus pressupostos, ele o faz a partir de uma crítica a elementos que aparecem (sem nunca estarem efetivamente) com um grau considerável de autonomização na sociedade civil-burguesa. Nosso autor também tem como ponto de partida a indissociabilidade das diferentes esferas do ser social; mas é levado a expô-las de modo mais ou menos apartado. Engels debate com autores que têm enfoque mais segmentado e, assim, no ímpeto de popularização do que viria a se tornar o marxismo, a clareza da exposição é valorizada, por vezes, em detrimento da explicitação das ligações e conexões meandradas entre as diferentes esferas da sociedade.

Isso faz com que saibamos as diferenças específicas de Marx e de Engels diante dos socialistas vulgares, o que não é pouco. Antes, numa época em que o movimento dos trabalhadores consegue conquistar posições no Estado, seria essencial.

O desenvolvimento do texto engelsiano nos leva, inclusive, a perceber que uma teoria revolucionária não poderia prescindir de uma crítica ao Direito e ao Estado. Porém, ao mesmo tempo, a divulgação e a exposição do autor abriram certo espaço para uma leitura segmentada e parcial de seu pensamento, o que não deixou de prejudicar o rigor e o cuidado necessários ao desenvolvimento de uma teoria marxista crítica. O legado de Friedrich Engels, para ser valorizado, precisa que se tenha em conta aquilo que sempre foi central ao nosso autor, a convergência entre as críticas à economia política, à religião, ao Estado e ao Direito. Ainda hoje, talvez isto seja central na leitura atenta desse autor.

\section{REFERÊNCIAS}

BERNSTEIN, Eduard. Socialismo evolucionário. Tradução Manuel Teles. Rio de Janeiro: Jorge Zahar, 1997.

CHASIN, José. Marx: estatuto ontológico e resolução metodológica. São Paulo: Boitempo, 2009.

CLAUDIN, Fernando. A crise do movimento comunista. Tradução José Paulo Netto. São Paulo: Expressão popular, 2012.

COTRIM, Lívia. Apresentação. In: MARX, Karl. Nova Gazeta Renana. Tradução Lívia Cotrim. São Paulo: Educ, 2010.

ENGELS, Friedrich. A questão da habitação. São Paulo, Editora Acadêmica, 1988.

ENGELS, Friedrich. Do socialismo utópico ao socialismo científico: Ludwig Feuerbach e o fim da filosofia clássica alemã. Tradução José Severo de C. Pereira. São Paulo: Fulgor, 1962. 
ENGELS, Friedrich. Esboço de uma crítica à economia política. Tradução Maria Filomena Vieras. Revista Temas de Ciências Humanas. São Paulo: Livr. Ed. Ciências Humanas, 5, 1979.

ENGELS, Friedrich. Prefácio. In: MARX, Karl. Guerra civil na França. Tradução Rubens Enderle. São Paulo: Boitempo, 2011b.

ENGELS, Friedrich. Prefácio. In: MARX, Karl. Lutas de classe na França. Tradução Nélio Schneider. Boitempo: São Paulo: 2012.

ENGELS, Friedrich. Prefácio da edição Francesa. In: MARX, Karl; ENGELS, Friedrich. Manifesto Comunista. Tradução de Álvaro Pina e Ivana Jikings. São Paulo: Boitempo, 1998.

ENGELS, Friedrich. Prefácio. In: MARX, Karl. O 18 Brumário de Luís Bonaparte.

Tradução de Nélio Schneider. São Paulo: Boitempo, 2011a.

GRESPAN, Jorge. Marx e a crítica ao modo de representação capitalista. São Paulo: Boitempo, 2019.

GRESPAN, Jorge. O negativo do capital. São Paulo: Expressão Popular, 2012.

HEGEL, F.W. Ciência da lógica 3, a doutrina do conceito. Tradução Christian G. Ilber; Federico Orsini. Petrópolis: Vozes, 2018.

HEGEL, F.W. Princípios da filosofia do Direito. Tradução Orlando Vittorino. São Paulo: Martins Fontes, 2003.

HOBSBAWM, Eric. A era do capital. Tradução Luciana Costa Neto. Rio de Janeiro: Paz e terra, 2007.

LUKÁCS. György. Para uma ontologia do ser social II. Tradução Nélio Schneider. São Paulo: Boitempo, 2013.

LUKÁCS. György. Prolegômenos para uma ontologia do ser social. Tradução Lya Luft e Rodnei Nascimento. São Paulo: Boitempo, 2010.

MARX, Karl. A guerra civil na França. Tradução Rubens Enderle. São Paulo: Boitempo, 2011.

MARX, Karl. As lutas de classe na França. Tradução Nélio Schneider. São Paulo: Boitempo, 2012a.

MARX, Karl. Crítica ao programa de Gotha. Tradução Rubens Enderle. São Paulo: Boitempo, 2012b.

MARX, Karl. Grundrisse. Tradução Mario Duayer. São Paulo: Boitempo, 2011.

MARX, Karl. Miséria da filosofia. Tradução José Paulo Netto. São Paulo: Global, 1989.

MARX, Karl. Nova Gazeta Renana. Tradução Lívia Cotrim. São Paulo: Educ, 2010. 
MARX, Karl. O 18 Brumário de Luis Bonaparte. Tradução Leandro Konder. Rio de Janeiro Paz e terra, 2002.

MARX, Karl. O capital, Livro I, Volume I. Traduçao Regis Barbosa e Flávio R. Kothe São Paulo: Nova Cultural, 1996a.

MARX, Karl. O capital. Livro I, Volume II. Tradução Regis Barbosa e Flávio R. Kothe São Paulo: Nova Cultural, 1996b.

MEDRADO, Nayara. Crime, sujeito e revolução: a questão penal em Marx. Dissertação de mestrado. Belo Horizonte: UFMG, Faculdade de Direito, 2018.

REICHELT, Helmut. Sobre a estrutura lógica do conceito de capital em Marx. Tradução Nélio Schneider. Campinas: Unicamp, 2013.

SARTORI, Vitor Bartoletti. Acerca de Karl Marx em Sobre a questão judaica. Revista de Ciências do Estado (UFMG), v. 5, p. 1-21, 2020 b.

SARTORI, Vitor Bartoletti. A crítica marxista do Direito diante de Friedrich Engels: a tensão entre exposição e pesquisa em sua análise da esfera jurídica. Revista On Line de Filosofia e Ciências Humanas, Belo Horizonte, v. 26, n. 2, 2020a.

SARTORI, Vitor Bartoletti. Apontamentos sobre dialética e história em Friedrich Engels. In: Revista On Line de Filosofia e Ciências Humanas, Belo Horizonte, n. 20, 2015.

SARTORI, Vitor Bartoletti. De Hegel a Marx: da inflexão ontológica à antítese direta, vol.55, n.130. Belo Horizonte: UFMG, 2014.

SARTORI, Vitor Bartoletti. Engels como crítico do direito e da igualdade jurídica: a luta por direitos e sua ambiguidade. Revista de Direitos e Garantias Fundamentais, Vitória, UFES, v. 18 , série 2,2018 a.

SARTORI, Vitor Bartoletti. Engels e a igualdade jurídica: notas acerca da questão da secularização da visão de mundo teológica no Direito. Revista Projeto História São Paulo: PUC SP, n. 68. 2018b.

SARTORI, Vitor Bartoletti. Marx e o "Direito do trabalho": a luta de classes, o terreno jurídico e a revolução. Katálisis, Santa Catarina, UFSC; v. 22, n. 2, 2019. 